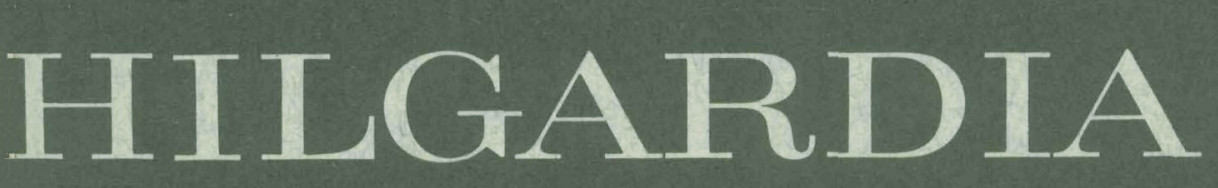

A JOURNAL OF AGRICULTURAL SCIENCE PUBLISHED BY THE CALIFORNIA AGRICULTURAL EXPERIMENT STATION

Volume 38, Number $7 \cdot$ June, 1967

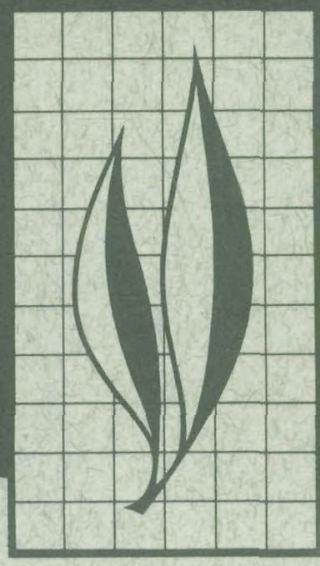

\title{
Iron Requirement Studies of Navel Orange Trees in Solution Cultures
}

E. F. Wallihan, M. J. Garber, J. R. Hammond, Wilma L. Printy, D. S. Rayner, and R. G. Sharpless 
Difficulties in controlling the supply of iron to citrus trees when grown in soil led the authors to use of nutrient solutions for this study. Twenty-four nucellar navel orange trees were grown for eleven years in individual tanks of nutrient solutions, out of doors. Eight of them were maintained at high-iron levels by regular additions of iron sulfate to the nutrient solutions. The remaining trees became iron deficient at various rates. Analyses of standard leaves, picked in the early fall season, provided a measure of the changing level of iron nutrition for each tree from year to year.

The results show that, when the concentration of iron in standard leaves was $30 \mathrm{ppm}$ or less for two consecutive years, the rate of tree growth and the numbers of fruit produced diminished. Fruit sizes were unaffected, except that in some years, fruit on irondeficient trees were somewhat larger than those on trees supplied with iron. Chemical differences in the fruit were slight except for iron concentrations. Fruits were lighter colored in iron-deficient trees.

Iron deficit was also accompanied by loss of leaves and dieback of twigs. This obvious symptom may provide a useful measure of the severity of iron deficit.

\section{THE AUTHORS:}

E. F. Wallihan is Associate Chemist in the Experiment Station and Associate Professor of Soil Science, Department of Soils and Plant Nutrition, Riverside.

M. J. Garber is Biometrician and Professor of Biometry, Biometrical Laboratory, Riverside.

J. R. Hammond is Laboratory Assistant, Department of Soils and Plant Nutrition, Riverside.

Wilma L. Printy, D. S. Rayner, and R. G. Sharpless are Laboratory Technicians, Department of Soils and Plant Nutrition, Riverside. 


\section{Iron Requirement Studies of Navel Orange Trees in Solution Cultures'}

\section{INTRODUCTION}

IRON DEFICIENCY in citrus trees occurs in many of the citrus-growing regions of the world. It is widely identified by visible symptoms, the most obvious of which is a characteristic interveinal chlorosis in the leaves. In California, from 5 to 10 per cent of the citrus acreage is affected-ranging in severity up to total loss of fruit production.

The checkered history of research on iron nutrition of plants in general offers little precedent for studies of iron requirement. One of the traditional 10 elements widely recognized for over a century as being essential to plants, iron has received much attention, particularly where deficiencies occur. However, during the first half of this century, when inorganic analyses of plant tissues were being used advantageously in nutrition research, progress in iron nutrition was retarded by the widespread conviction (Iljin, 1952, and McGeorge, 1949) that a consistent relation between deficiency symptoms and internal iron concentrations did not exist. It now seems clear (Jacobson, 1945; Smith, Reuther, and Specht, 1950, and Wallihan, 1955) that at least some of the tissue analyses on which this conclusion was based were subject to large errors due to surface contamination by soil dust. Of all the known essential elements, iron generally occurs in the highest concentrations in soils relative to the concentrations present in plant tissues. This ratio commonly falls in the range from $10^{2}$ to $10^{4}$, and indicates that soil dust is a serious source of iron contamination of plant tissues.

The relation between iron deficiency chlorosis and internal iron concentration in recently matured citrus leaves has been established with reasonable precision (Smith et al., 1950, and Wallihan, 1955). Little is known, however, of the relation between level of iron nutrition and fruit production. Field observation reveals that extreme iron deficiency may cause total lack of fruit production and even death of the tree. Stewart and Leonard (1954) showed that in the acid sands of central Florida, severely defoliated, highly iron-deficient citrus trees could be brought into good fruit production by applying iron chelate to the soil. Mild iron chlorosis, however, appears to be compatible with high fruit production.

It is the middle range of deficiency that presents two problems in California soils-both related to soils of medium to fine texture that contain calcium carbonate. First, a dependable procedure for increasing the iron supply to the tree has not been discovered (Wallihan and Embleton, 1961); therefore, controlled iron levels cannot be established for experimental purposes. Second, the conditions that cause iron deficit may also affect fruit production directly, in addition to the effects on iron supply itself. Hence, the association between fruit production and level of iron

\footnotetext{
${ }^{1}$ Submitted for publication July 11, 1966.
} 
nutrition may be a secondary relationship.

For the study reported here on the effects of controlled iron supply on orange trees, an aerated solution culture installation was maintained in an outdoor environment comparable to commercial orchards.

\section{MATERIALS AND METHODS}

Nucellar navel orange scions were grafted on one-year-old Troyer citrange seedlings in June, 1950, grown for one year in soil, and transferred to solution cultures in August, 1951.

The outdoor solution culture "orchard" installation was essentially that described by Chapman, Brown, and Rayner (1947) and Chapman et al., (1958). Twenty-four trees were grouped in a rectangular block of tanks, six tanks long and four tanks wide, spaced on 10 -foot squares. The block was bordered on the east and west by similar trees in other experiments. The tanks, which were three-fourths buried in the ground, consisted of cylindrical cement conduit sections with poured concrete bottoms, about four feet in diameter and four feet deep, with a capacity of 700 liters. An overhead pipe framework carried compressed air for continuous aeration of the nutrient solutions and pro- vided support for the trees, which were suspended from the frame by wires. Split concrete covers on the tanks protected the solutions from debris and access of light, yet provided access to the roots and solutions.

Each nutrient solution contained the following initial concentrations of essential elements expressed as parts per million (ppm): calcium (Ca), 50; potassium $(\mathrm{K}), 20$; nitrogen $(\mathrm{N}), 49$; magnesium $(\mathrm{Mg}), 12$; phosphorus $(\mathrm{P})$, 4; $\operatorname{sulfur}(\mathrm{S}), 8$; manganese $(\mathrm{Mn}), 0.2$; boron (B), 0.1; zine ( $\mathrm{Zn}), 0.1$. The tap water used to make up the nutrient solutions provided all of the needed calcium, plus unimportant amounts of sodium (Na), $\mathrm{Mg}$, chlorine ( $\mathrm{Cl}$ ), and $\mathrm{S}$. The other elements were supplied by adding $720 \mathrm{ml}$ of a nutrient stock solution to each tank with the following composition:

\begin{tabular}{|c|c|c|}
\hline \multicolumn{2}{|c|}{ Component } & \multirow{2}{*}{$\frac{\text { Quantity }}{(m l)}$} \\
\hline & & \\
\hline Nitric acid & $\mathrm{HNO}_{3}$ (CP conc.) & 2300 \\
\hline Magnesium nitrate & $\mathrm{Mg}\left(\mathrm{NO}_{3}\right)_{2}($ comm'l $4 \mathrm{~N})$ & 3600 \\
\hline Potassium sulfate & $\mathrm{K}_{2} \mathrm{SO}_{4}(\mathrm{CP} 1 \mathrm{~N}) \ldots$ & 7000 \\
\hline Phosphoric acid & $\mathrm{H}_{3} \mathrm{PO}_{4}(\mathrm{CP} 85 \%)$ & 160 \\
\hline Boric acid & $\mathrm{H}_{3} \mathrm{BO}_{3}(\mathrm{CP} 5 \mathrm{mg} \mathrm{B} / \mathrm{ml})$ & 350 \\
\hline Manganese chloride & $\mathrm{MnCl}_{2}(\mathrm{CP} 10 \mathrm{mg} \mathrm{Mn} / \mathrm{ml})$ & 350 \\
\hline Zine sulfate & $\mathrm{ZnSO}_{4}(\mathrm{CP} 5 \mathrm{mg} \mathrm{Zn} / \mathrm{ml})$ & 350 \\
\hline
\end{tabular}

Unknown quantities of copper $(\mathrm{Cu})$ and molybdenum (Mo) present in the water and various salts were adequate for the needs of the plants. Iron was supplied as desired from iron sulfate $\left(\mathrm{FeSO}_{4}\right)$ solution containing $10 \mathrm{mg}$ Fe per ml. Water used by the trees was replaced with deionized water to avoid increases in salt concentrations.
$\mathrm{pH}$ values were checked routinely three times a week using a glass electrode. Since the drift was usually toward higher $\mathrm{pH}$ values, due to removal of nitrate ions, nitric acid was used to compensate. Downward drift occurred in the spring with renewed shoot growth and flower development and was corrected by adding KOH. During the 
first five years of growth, $\mathrm{pH}$ was maintained in the range 4.0 to 4.5 , following recommendations of Chapman et al. (1947). However, iron concentrations in leaves remained at high levels even though iron was not added to the nutrient solutions. On the assumption that dust falling in the nutrient solution provided an adequate supply of iron at this $\mathrm{pH}$, the maintained $\mathrm{pH}$ range was raised to 5.0 to 5.5. Leaf iron concentrations then began to decline.

Nutrient solutions were routinely discarded at two-month intervals and replaced with fresh solutions. Between solution changes, samples of all solutions were tested for $\mathrm{NO}_{3}, \mathrm{PO}_{4}$, and $\mathrm{Ca}$ at two-week intervals, and these elements added as needed. After the initial inclusion of $\mathrm{K}$, it was found that the trees maintained an adequate concentration in the leaves (about 2 per cent) with only the $\mathrm{K}$ provided in the fresh nutrient solutions every two months.

Iron treatments were started in October, 1956. The intended treatment differential involved three iron levels, each applied to eight trees, with completely randomized distribution. The high-iron trees received $0.1 \mathrm{ppm}$ of iron added to the nutrient solutions once each week from late 1956 to 1959 and twice each week thereafter. We expected the level of iron nutrition in the remaining 16 trees to decline rather rapidly and uniformly and intended to start supplying iron at the appropriate time to half of them at an intermediate rate. Actually, the decline was quite slow and varied among individual trees. We decided, therefore, to withhold iron from the entire group of 16 trees and accept the differences in iron levels that occurred without differential treatment. The experiment, therefore, consisted of eight trees (treated) that received regular additions of $\mathrm{FeSO}_{4}$ and 16 trees to which no iron was added (untreated).

In 1960, one untreated tree became very pale, and almost completely defoliated, with the root system deterior- ated. Upon finding an abrupt rise in copper concentration in the leaves, we began regular additions of $\mathrm{FeSO}_{4}$. Within a year the tree had recovered but was eliminated from the experiment, because treatment was no longer comparable to that of other trees. This left a total of 15 untreated trees.

Aside from the nutrient solutions, routine care of the trees-including insect pest control and orchard heating during winter-was the same as that required in commercial citrus orchards in soil. The major environmental problem was wind damage, in spite of 10 -foot windbreak fences on the north and south sides of the orchard. One particular windstorm in November, 1961, characterized by high velocity, high temperature, and low humidity caused severe loss of leaves and fruit that certainly influenced the yield records for that year.

Nutritional levels of all trees were checked annually (starting in 1956) by analysis of leaf samples taken in the September-October period. The leaves selected were those initiated at the time of spring bloom on nonfruit-bearing terminals, hereafter referred to as standard leaves. All leaves were washed individually with Ivory soap using a one-inch nylon paint brush, rinsed in tap water and dried with a clean towel that had been laundered by hand with Ivory soap and dried on a nonmetallic line. Analytical methods were as follows: $\mathrm{Ca}, \mathrm{K}$, and $\mathrm{Na}$, flame photometer using $\mathrm{Li}$ as internal standard; P, colorimetric (Fiske and Subbarow, 1925); $\mathrm{Mg}$, titration with sodium ethylene diamine tetra acetate (EDTA) after removal of $\mathrm{Ca}$; N, micro-Kjeldahl; $\mathrm{Fe}$, O-phenanthroline and $\mathrm{Mn}$, ammonium persulfate oxidation (Sandell, 1950); $\mathrm{Zn}$, zincon (Johnson and Ulrich, 1959); $\mathrm{Cu}$, zincon (Chapman and Pratt, 1961).

Fruit was harvested in January or early February of each year, and, in each case, the yield was reported as the previous year's crop. Samples of fruits 
were taken from the 1957 and 1960 crops for study of fruit composition and quality. Juice, pulp, and rind fractions were separated and analyzed for inorganic constituents. Juice was also analyzed for sugar with the refractometer, total acid by titration with $\mathrm{NaOH}$ to phenolphthalein, and ascorbic acid by oxidation with iodine. Flavor tests were inconclusive, because differences in individual taste exceeded differences due to treatment, although quality was generally high.

In January, 1958, a line was painted around each trunk at the point of minimum diameter about eight inches above the bud union. At yearly intervals, circumference of the trunk at this line was measured with steel tape.
The experiment was terminated in 1962, at which time samples of trunk wood were taken for analysis for iron. The trees were crowded for space, both roots and tops. By the end of the 1960 season, the root systems of some trees were packed tightly in the tanks. Also, the tree canopies provided such complete shade that lower limbs started to defoliate. It was felt that pruning would disturb the pattern of nutrition and fruit production so much that, by the time a new pattern was established, the crowded condition would return. These considerations led to the decision to terminate the experiment.

Statistical tests of the data were done by analyses of variance and covariance.

\section{RESULTS}

\section{General nutrition level of trees}

The annual leaf analyses, summarized in table 1, made possible an assessment of general nutritional levels of the trees on the basis of published indexes for standard leaves (Reuther and Smith, 1954).

Nitrogen tended to be on the high end (2.4 to 2.7 per cent) of the recommended range. However, the one very high level (4.3 per cent $\mathrm{N}$ ) was associated with very low fruit production due to extreme iron deficiency. The remain- ing figures represent tolerable $\mathrm{N}$ levels.

Phosphorus also tended to be somewhat high. The reason for some of the highest $\mathrm{P}$ concentrations found in leaves will be discussed in a subsequent section.

Potassium varied rather widely and almost bracketed the acceptable range from 0.6 to 2.3 per cent.

Sodium concentrations were not high enough to cause toxicity. Its presence in the plants in measurable concentrations, however, was probably caused by the $\mathrm{Na}_{2} \mathrm{CO}_{3}$ solution, which was used to re-

TABLe 1

SUMMARY OF ANALYSES OF STANDARD LEAVES

\begin{tabular}{|c|c|c|c|c|c|c|}
\hline \multirow{2}{*}{ Component } & \multicolumn{6}{|c|}{ Year } \\
\hline & 1956 & 1957 & 1958 & 1959 & 1960 & 1961 \\
\hline Nitrogen (per cent). & $\mathrm{ND}^{*}$ & ND & ND & $2.4-3.2$ & $2.6-3.1$ & $2.9-4.3$ \\
\hline Calcium (per cent).. & $1.88-4.27$ & $2.2-3.8$ & $2.2-4.3$ & ND & $2.8-4.5$ & $2.4-3.9$ \\
\hline Magnesium (per cent)..... & ND & ND & $0.6-1.0$ & $0.6-1.1$ & $0.9-2.1$ & $0.7-1.6$ \\
\hline Potassium (per cent)..... & $0.99-2.08$ & $1.1-1.7$ & $0.7-1.3$ & ND & $0.5-1.6$ & $0.8-2.0$ \\
\hline Sodium (per cent) ........ & $0.03-0.14$ & $0.06-0.15$ & $0.03-0.13$ & ND & $0.12-0.36$ & $0.06-0.15$ \\
\hline Phosphorous (per cent) ... & $0.12-0.21$ & $0.13-0.19$ & $0.18-0.28$ & $0.14-0.23$ & $0.11-0.18$ & $0.14-0.31$ \\
\hline Iron $(\mathrm{ppm}) \ldots \ldots \ldots \ldots$ & $36-95$ & $36-108$ & $16-76$ & $22-95$ & $19-102$ & $12-53$ \\
\hline Manganese $(\mathrm{ppm}) \ldots$. & $17-38$ & $14-41$ & $10-28$ & $11-31$ & $11-44$ & $6-34$ \\
\hline Zinc $(p p m) \ldots \ldots$ & $18-43$ & $14-25$ & $11-21$ & $17-27$ & $18-34$ & $11-35$ \\
\hline Copper $(\mathrm{ppm}) \ldots$ & $5-9$ & 4-9 & $3-11$ & $5-18$ & $4-26$ & $4-18$ \\
\hline
\end{tabular}

* ND indicates that no determination was made. 
TABLE 2

AVERAGE IRON CONCENTRATIONS IN STANDARD LEAVES (SAMPLED ANNUALLY 1956 TO 1961), AND IN TRUNK WOOD (AT THE END OF THE EXPERIMENT) IN RELATION TO IRON SUPPLY

\begin{tabular}{|c|c|c|c|c|c|c|c|}
\hline \multirow{3}{*}{ Treatment of trees } & \multicolumn{7}{|c|}{ Average iron concentrations in: } \\
\hline & \multicolumn{6}{|c|}{ Leaves } & \multirow{2}{*}{$\frac{\text { Trunk wood }}{1962}$} \\
\hline & 1956 & 1957 & 1958 & 1959 & 1960 & 1961 & \\
\hline & ppm & ppm & ppm & ppm & $p p m$ & ppm & $p p m$ \\
\hline Iron supplied (8) . . . . & 62.6 & 88.0 & 82.8 & 82.6 & 70.9 & 46.1 & 22.4 \\
\hline Iron not supplied $(15) \ldots \ldots \ldots$ & 61.1 & 45.8 & 29.8 & 34.2 & 31.4 & 16.9 & 12.2 \\
\hline Significance $\ldots \ldots \ldots \ldots \ldots \ldots$ & NS & $* * *$ & $* * *$ & $* * *$ & $* * *$ & $* * *$ & $* * *$ \\
\hline
\end{tabular}

*** Significant at the .001 level.

$\mathrm{NS}=$ Not found to be significant.

generate the anion exchange bed in the water deionizer installation.

Calcium concentrations also covered a wide range, but remained within the tolerance range from 1.6 to 7.0 . Calcium concentrations in citrus leaves increase with age (Smith and Reuther, 1950), which may account for part of the variation observed in this study.

Magnesium values tended to be high in some trees. Certainly, there was no evidence of deficiency. If the higher values were excessive, the effects on the trees were not obvious. Any tendency for inverse correlation with $\mathrm{K}$ concentration was modest.

Iron varied widely, as intended, with numerous values below the critical concentration of 35 ppm suggested by Reuther and Smith (1954). This element will be discussed more extensively.

Manganese was supplied when nutrient solutions were replaced, but no additions were made between changes. The lowest leaf concentrations observed were slightly below the recommended minimum of $15 \mathrm{ppm}$. Yield response to Mn sprays has not been reported for leaf levels of $\mathrm{Mn}$ above $10 \mathrm{ppm}$, but it is possible that the trees having 6 to $9 \mathrm{ppm}$ Mn would have responded somewhat to increased supply.

Zinc levels were adequate, with the possible exception of one tree that dropped to $11 \mathrm{ppm}$ in 1958 and one tree in 1961. Following the 1958 leaf analyses, in which an overall decrease in $\mathrm{Zn}$ concentration was evident, routine addition of $\mathrm{Zn}$ to nutrient solutions was started.

Copper concentrations were certainly adequate and probably not excessive. The one tree with $26 \mathrm{ppm} \mathrm{Cu}$ was very deficient in iron (19 ppm) and low in Mn (14 ppm). This can be interpreted in terms of antagonism, but the causeeffect relationship is uncertain.

\section{Iron nutrition}

Table 2 gives the average iron concentrations in standard leaves from all the trees in the experiment from 1956 through 1961, and in the trunk wood sampled at the time the experiment was terminated. Differential iron treatments caused significant differences in tissue iron concentrations in all years after 1956, when such treatments were started.

For the experiment as a whole, leaf iron concentrations varied from year to year inversely with fruit yields; for the years 1956 through 1960, the correlation coefficient $r=-.91$ (fig. 1 ). This effect was more striking in the records for individual trees (fig. 2). The most probable explanation is that the iron supply iailed to meet the demand in years of high growth rate. A reciprocal relation apparently did not occur in 1961 be- 


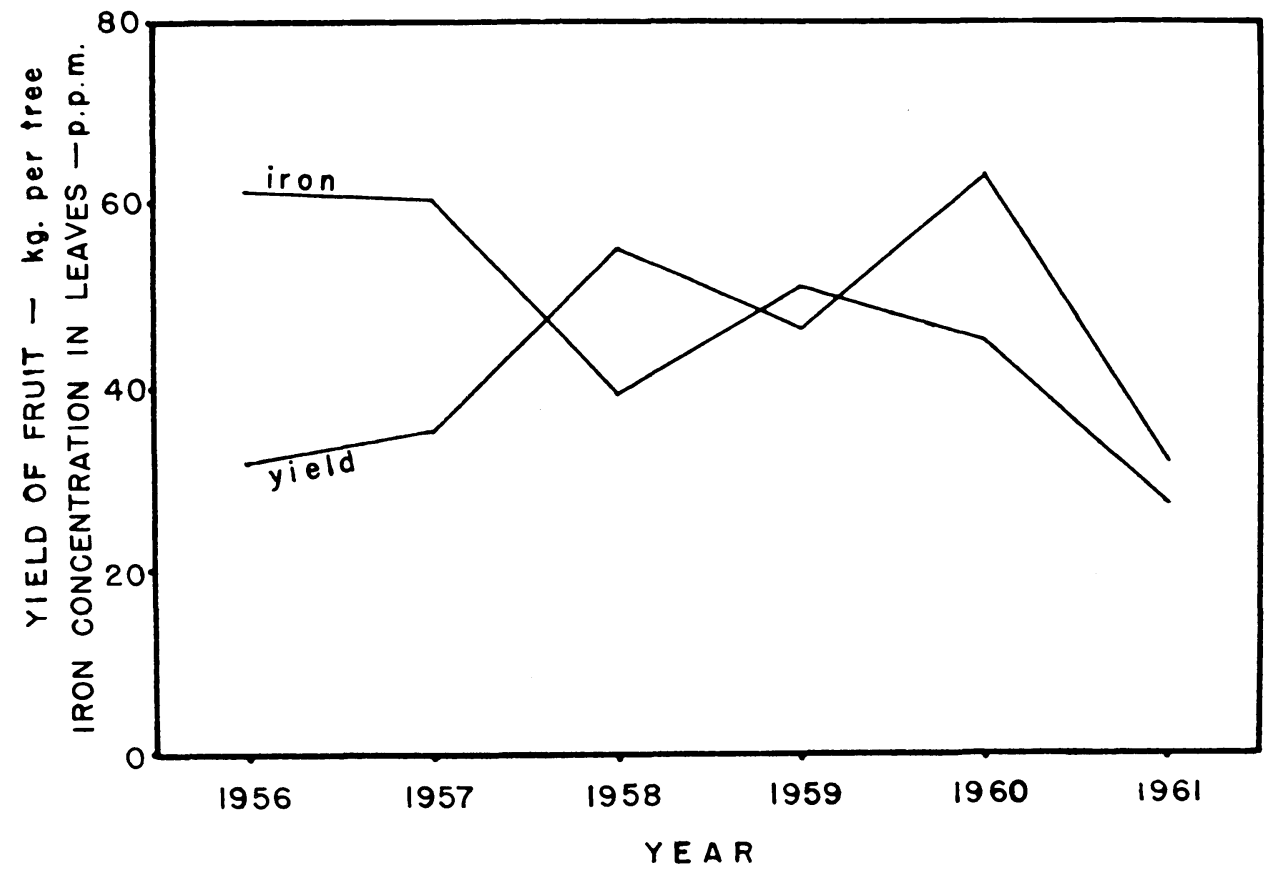

Fig. 1. Mean annual yields of fruit and concentrations of iron in standard leaves.

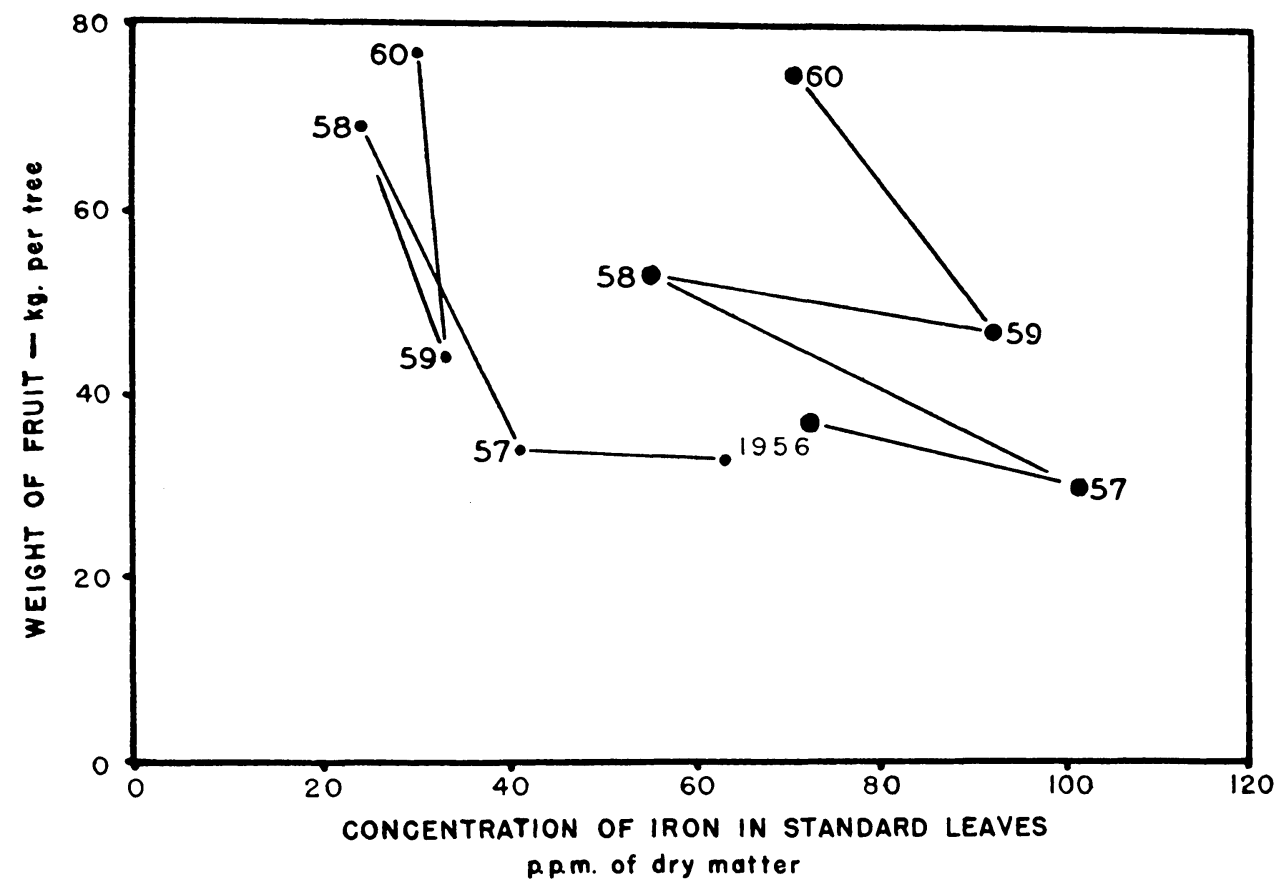

Fig. 2. Relation between yield of fruit and iron concentration in standard leaves during five successive years, in one high-iron tree (large dots) and one low-iron tree (small dots). 
cause of severe wind losses of nearly mature fruit.

In conformity with previous evidence (Bingham, Martin, and Chastain, 1958; Wallihan, 1955), phosphorus concentration tended to rise in iron-deficient leaves. Although the number of trees involved was not large enough to allow a precise evaluation of the relationship, it is interesting to note that in all leaf samples having iron concentrations less than $20 \mathrm{ppm}$, phosphorus was from 0.18 to 0.31 per cent. The modal value for the entire experiment was 0.15 per cent. Values higher than this are usually not achieved simply by increasing phosphorus supply (Chapman and Rayner, 1951), but presumably result from metabolic influences on phosphorus retention by the plant. Similar effects on leaf phosphorus concentrations have been shown to result from deficiencies of nitrogen (Chapman and Liebig, Jr., 1940; Cullinan and Batjer, 1943; McCalla and Woodford, 1938), sulfur (Chapman and Brown, 1941), and zine (Haas, 1936; Kelley and Cummins, 1920; Reed, 1946).

The visible symptoms of iron deficit in this experiment were similar to those that were commonly observed in the field-with one exception: Whereas field trees often develop severe chlorosis on individual limbs located at random positions around the tree, trees in the present experiment exhibited iron deficiency symptoms rather uniformly over the entire crown. This difference presumably related to uniformity of the solution culture as a root medium in contrast with the comparative variability of soil.

\section{Fruit production}

General characteristics: Average production for 1958, 1959, and 1960 was $55 \mathrm{~kg}$ per tree per year, which is comparable to productivity of field trees of the same age (Batchelor, Parker, and McBride, 1928). Production levels of individual trees during the same period are indicated by the following frequency distribution:

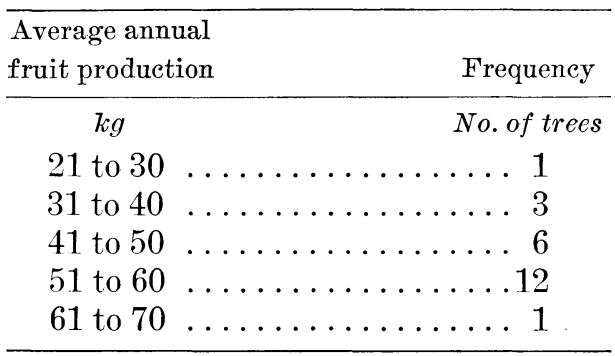

The skewed distribution reflects two conditions: (1) three trees with lowest production were severely deficient in iron, and (2) two other trees were weak producers throughout for unknown reasons. Each of the remaining 18 trees reached a peak yield, in one year or another, that was close to the maximum for the year. No one tree was outstandingly productive in more than one year.

Relation to iron nutrition: The graphs in figure 3 show the relation between leaf iron concentrations in standard leaves and fruit production for the years 1956 through 1961. Coincident with the progressive reduction in leaf iron concentrations in the untreated trees after 1956 (table 2) is a reduction in yield by an increasing number of trees. Using as a reference the general level of production of the treated trees, smaller yields were produced by four trees in 1957, four in 1958, seven in 1959 , eight in 1960, and 12 in 1961. Five of the latter group had leaf iron concentrations ranging from 12 to 19 ppm and yielded less than $10 \mathrm{~kg}$ of fruit per tree.

Figure 3 suggests that the critical concentration of iron for fruit production was less than $40 \mathrm{ppm}$ and probably not less than $30 \mathrm{ppm}$. When trees were classified into two groups having high and low leaf iron concentrations, respectively, significance of the yield difference was greater when the dividing line was $30 \mathrm{ppm}$ than when it was 35 ppm, indicating that the critical concentration was closer to $30 \mathrm{ppm}$. 


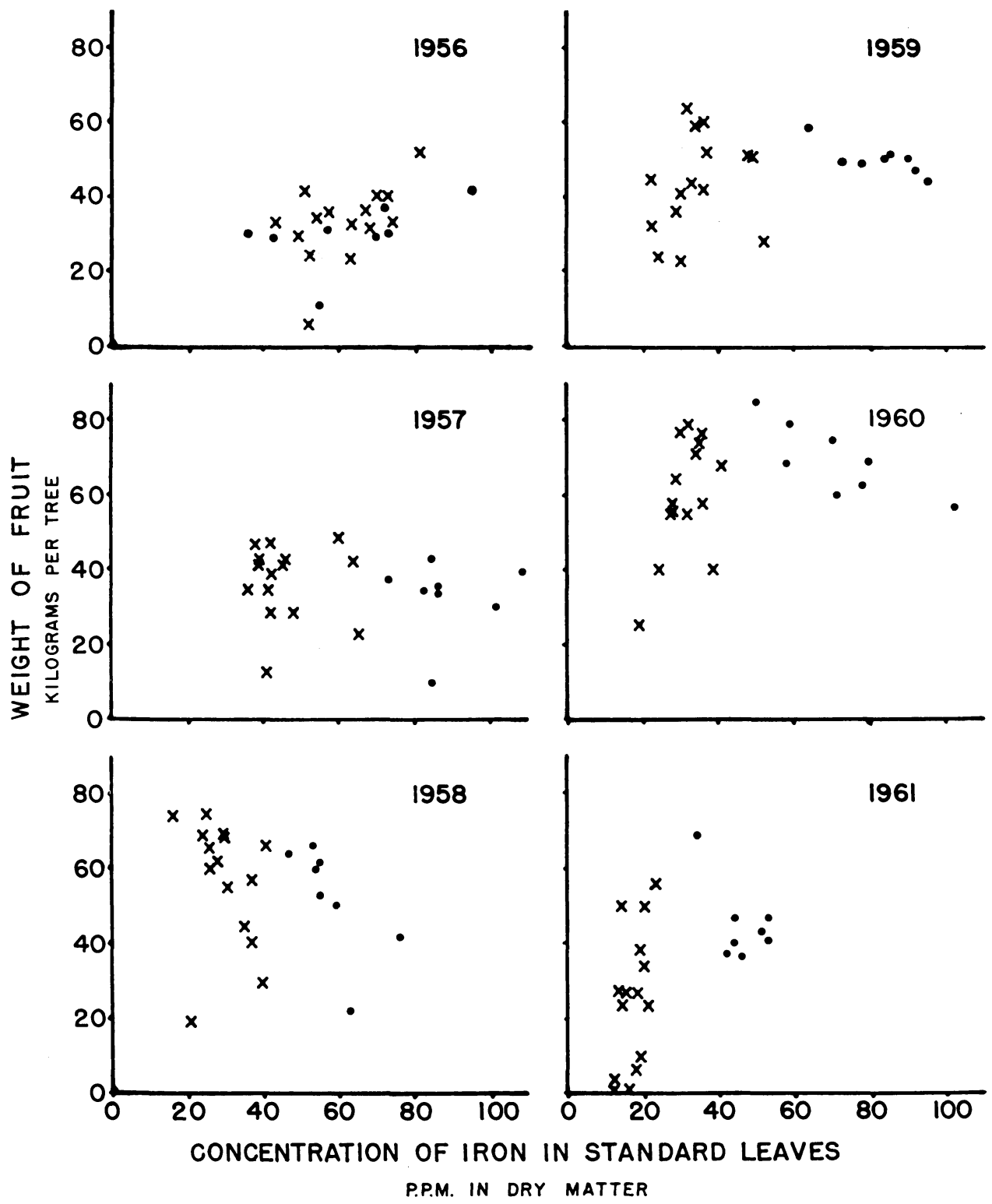

Fig. 3. Relation between yield of fruit and concentration of iron in standard leaves. Dots represent trees that received added iron starting in the autumn of 1956.

Table 3 shows the average yields of fruit in treated and nontreated trees from 1958 through 1961 . Table 4 shows the average yields when the trees are grouped according to leaf iron concentrations. This measure of the level of iron nutrition is used in two ways, de- pending on the duration of iron deficit. In one comparison, trees having leaf iron concentrations of $30 \mathrm{ppm}$ or less in a particular year are classified as iron deficient in that year, and the remaining trees are regarded as adequately supplied. In the other comparison, the iron- 
deficient trees had leaf iron concentrations of $30 \mathrm{ppm}$ or below in two consecutive years.

The comparison based on iron supply was of little value, as might be expected, since symptoms of iron deficit and leaf iron concentrations in untreated trees varied widely. Comparisons based on "current" leaf iron concentrations showed significant difference above the .05 level only in 1959 . Comparisons based on low leaf iron concentrations in two consecutive years showed significant differences at the .01 level or higher in 1959 and 1961, thus suggesting a cumulative effect of iron deficit.

Average annual vield figures are also shown in terms of fruits per tree and weight per fruit in relation to treatment (table 5) and iron concentrations in leaves (table 6 ). These data indicate that reduction in yield in low-iron trees was caused by reduction in number of fruits matured, although the difference in 1960 was not shown to be significant. Weights of the individual fruits were actually somewhat greater in the lowiron trees than in high-iron trees in 1959 and 1961. As in the case of total yield (table 3), grouping of trees according to leaf iron concentrations appeared to provide a more sensitive measure of nutritional influence than did grouping by level of iron supply.

\section{Composition of fruit}

Proportions of juice, pulp, and rind in the fruits, and concentrations of total acid and sugar, are given in table 7 for the crops of 1957 and 1960, with trees grouped according to treatment. Ascorbic acid concentration in the juice was determined only in 1960. The differences between treatments in 1957 were slight and not found to be significant. In 1960, fruit from nontreated trees had a significantly larger fraction of rind and a lower percentage of sugar in the juice. Both of these differences constitute reduction in fruit quality
TABLE 3

AVERAGE FRUIT YIELDS PER TREE IN RELATION. TO IRON TREATMENT, IN SUCCESSIVE YEARS

\begin{tabular}{c|c|c|c}
\hline & \multicolumn{2}{|c|}{ Average weight of fruit per tree } & \\
\cline { 2 - 3 } & $\begin{array}{c}\text { Iron added } \\
\text { (8 trees) }\end{array}$ & $\begin{array}{c}\text { Iron not added } \\
\text { (15 trees) }\end{array}$ & Sig. \\
\hline & $k g$ & $k g$ & \\
$1958 \ldots \ldots \ldots$ & 52.3 & 56.8 & NS \\
$1959 \ldots \ldots \ldots$ & 50.0 & 44.1 & NS \\
$1960 \ldots \ldots \ldots$ & 69.5 & 59.9 & NS \\
$1961 \ldots \ldots \ldots$ & 44.8 & 25.0 & $*$ \\
\hline
\end{tabular}

* Significant at the 05 level.

$\mathrm{NS}=$ Not found to be significant.

associated with iron deficiency. Differences in juice, pulp, total acid, and ascorbic acid were not found to be significant.

Analyses of ash constituents in juice, pulp, and rind, as related to treatment, are given in table 8 . Iron concentrations were consistently higher in the fruit fractions from treated trees in both years, although the differences are less striking than those found in leaves (table 2).

Average total iron in the 1960 fruit crop (calculated from data in tables 3 and 8) was $142 \mathrm{mg}$ per tree in the treated trees and $70 \mathrm{mg}$ per tree in the nontreated trees. The estimated total annual iron requirement of a tree would be in the vicinity of $500 \mathrm{mg}$ (calculated on the assumption that a tree contains $15 \mathrm{~kg}$ of leaves [Cameron and Appleman, 1934], half of which may be produced in one year). Thus, iron removal in the fruit crop appears to represent a small part of the total iron uptake.

Of the other elements determined in 1957, zine was slightly lower in the rind of low-iron trees. In 1960, manganese, zine, and copper concentrations were lower in the pulp and rind of low-iron trees. Although the reason for these differences is not clear, they may be caused by impurities in the ferrous sulfate added to the treated trees. $\mathrm{CP}$ or re- 


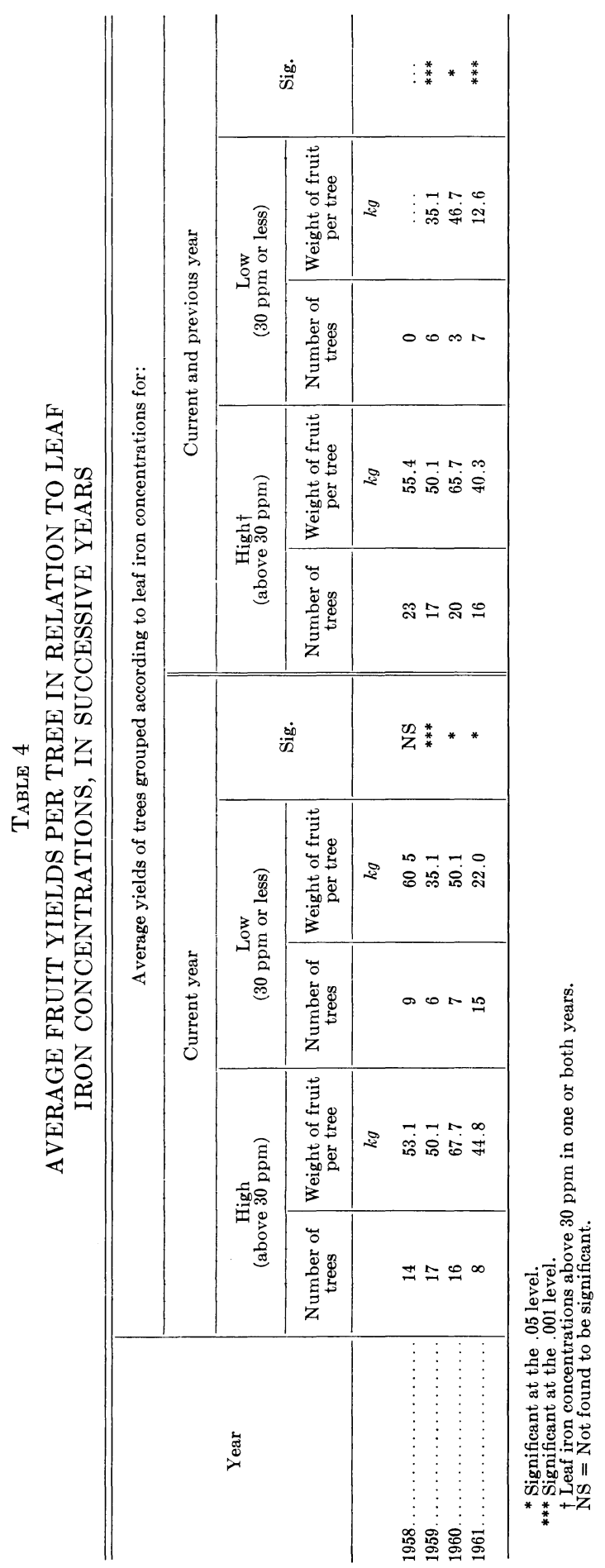


TABle 5

AVERAGE NUMBERS OF FRUITS PER TREE AND WEIGHTS OF INDIVIDUAL FRUITS IN RELATION TO IRON TREATMENT, IN SUCCESSIVE YEARS

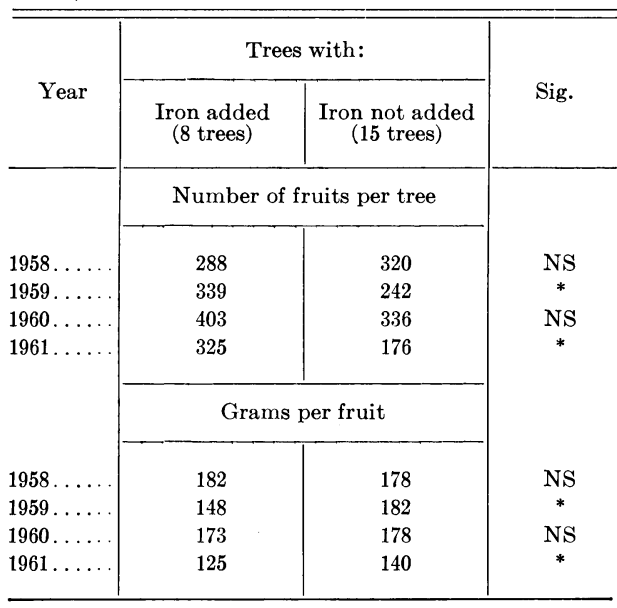

* Significant at the .05 level.

$\mathrm{NS}=$ Not found to be significant. agent-grade ferrous sulfate typically contains 0.05 per cent $\mathrm{Mn}$ and 0.005 per cent each of $\mathrm{Zn}$ and $\mathrm{Cu}$, compared with 20 per cent Fe. However, these amounts represent increases of only 2 per cent in annual Mn supply and 0.4 per cent increase in Zn supply.

\section{Leaf duration}

In cases of moderate deficiency of iron, young leaves become chlorotic during the period of rapid expansion, but they soon turn green, presumably because of the continued absorption of iron and the increase in iron concentration after the leaf stops growing (Smith et al., 1952). This level of chlorosis is illustrated in figure 4 . When the supply of iron was smaller, mature leaves developed some additional chlorophyll but never achieved a normal, dark green color (fig. 5). When the iron supply was

TABLE 6

AVERAGE NUMBERS OF FRUITS PER TREE AND AVERAGE WEIGHTS OF INDIVIDUAL FRUITS IN RELATION TO LEAF IRON CONCENTRATIONS, IN SUCCESSIVE YEARS

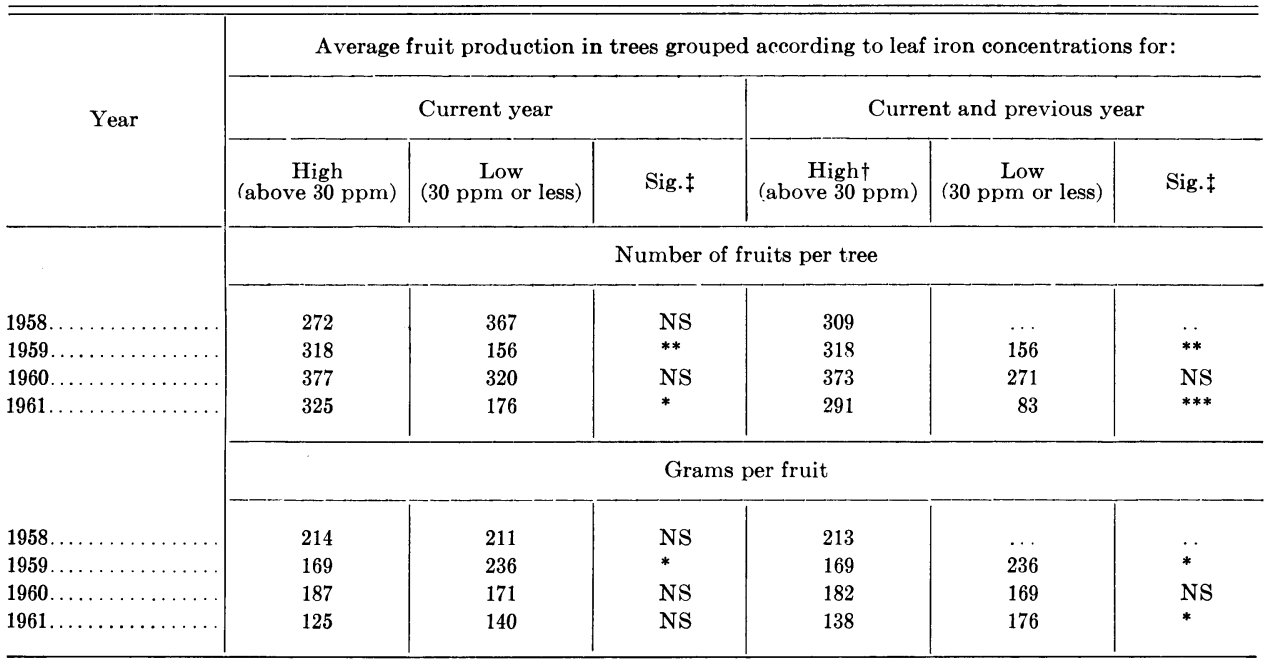

* Significant. at the .05 level.

** Significant at the .01 level.

** Significant at the .001 level.

$\dagger$ Leaf iron concentrations above $30 \mathrm{ppm}$ in one or both years.

$\ddagger$ Numbers of trees involved are the same as shown in table 4 .

$\mathrm{NS}=$ Not found to be significant. 
TABLE 7

AVERAGE JUICE, PULP, AND RIND PERCENTAGES IN FRUITS, AND ORGANIC CONSTITUENTS IN JUICE AS RELATED TO IRON TREATMENT

1957 AND 1960

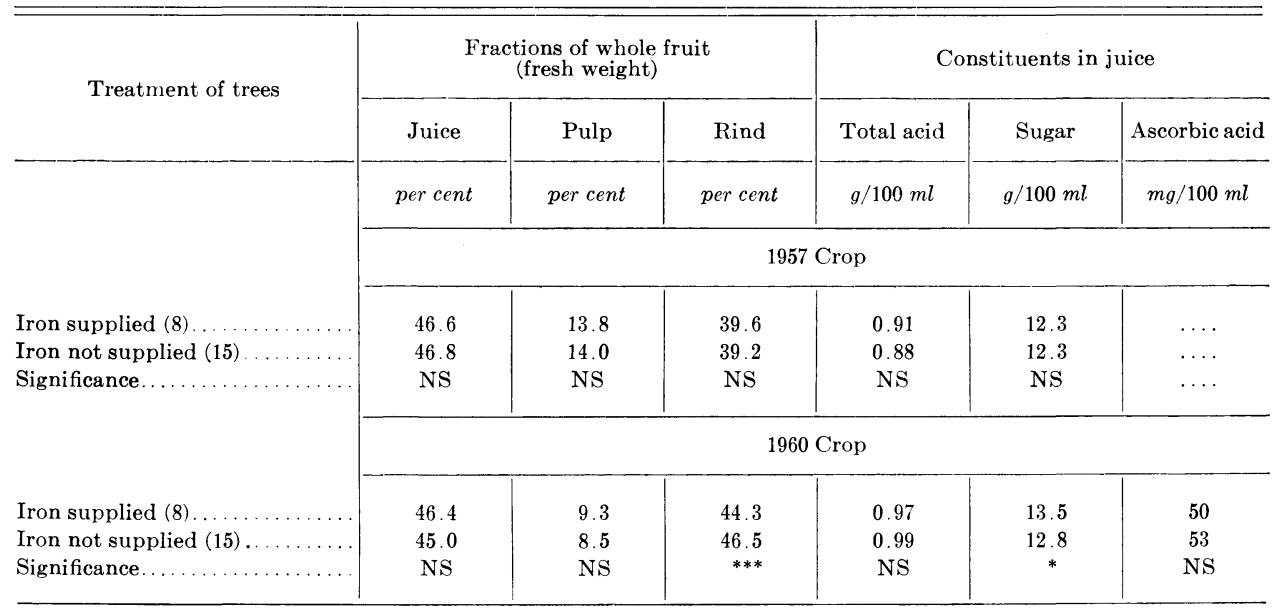

* Significant at the .05 level.

*** Significant at the .001 level.

$\mathrm{NS}=$ Not found to be significant.

sufficiently low, production of chlorophyll in young leaves occurred so slowly that the leaf failed to become self-supporting and died-resulting ultimately in the death of the twig (fig. 6).

\section{Trunk growth}

Trunk circumference increased by 7.0 $\mathrm{cm}$ on the treated trees and $6.4 \mathrm{~cm}$ on the nontreated trees during the final four years of the experiment. The difference was not found to be significant. Table 9 shows the average annual increments in trunk circumference in trees grouped according to the high or low leaf iron concentrations. Significant regression between trunk growth and fruit production was not found.

\section{DISCUSSION}

The relation between iron nutrition and growth features of the plant-both vegetative and fruiting - appears to be more complex than it is for other nutrient elements. In this experiment, the initial appearance (1958) of severe chlorosis and low concentrations of iron in standard leaves did not cause any measurable reduction in fruit yield; but, where these conditions continued for two or more years, the depression of growth and fruit production became increasingly evident. One plausible explanation is that two or three older cycles of normal leaves remained on the tree when iron-deficient leaves first appeared. Apparently, the photosynthetic capacity of the older leaves was sufficient to cause a normal crop of fruit to set and mature. However, where iron supply was also deficient the following year, the total chlorophyll content of the tree was substantially reduced by the abcission of the oldest leaves, so that fewer fruits become established.

Responsibility for this complex relation between iron nutrition and growth probably lies in the relative immobility of iron in the plant. Evidence of many kinds indicates that iron, once located in the leaf parenchyma cells, never departs. Thus, the iron supply for newly developing tissues must come from the nutrient source via the xylem, and it 
TABLE 8

AVERAGE CONCENTRATIONS OF CERTAIN ASH CONSTITUENTS IN FRUIT FRACTIONS, AS RELATED TO IRON TREATMENT 1957 AND 1960

\begin{tabular}{|c|c|c|c|c|c|c|c|c|}
\hline \multirow{2}{*}{ Treatment of trees } & \multicolumn{8}{|c|}{ Constituent } \\
\hline & $\mathrm{Ca}$ & $\mathrm{Mg}$ & $\mathbf{K}$ & $\mathrm{P}$ & $\mathrm{Fe}$ & $\mathrm{Mn}$ & $\mathrm{Zn}$ & $\mathrm{Cu}$ \\
\hline \multirow{4}{*}{$\begin{array}{l}\text { 1957: } \\
\quad \text { Iron supplied....... } \\
\text { No iron supplied .... } \\
\text { Significance. ........ }\end{array}$} & per cent & per cent & per cent & per cent & $p p m$ & $p p m$ & $p p m$ & ppm \\
\hline & \multicolumn{8}{|c|}{ Juice } \\
\hline & $\begin{array}{l}\cdots \\
\cdots \\
\cdots\end{array}$ & $\begin{array}{l}\cdots \\
\cdots \\
\cdots\end{array}$ & $\begin{array}{l}\cdots \\
\cdots \\
\cdots\end{array}$ & $\begin{array}{l}0.18 \\
0.18 \\
\text { NS }\end{array}$ & $\begin{array}{c}12.3 \\
10.2 \\
* *\end{array}$ & $\begin{array}{l}1.6 \\
1.5 \\
\text { NS }\end{array}$ & $\begin{array}{l}5.3 \\
4.7 \\
\text { NS }\end{array}$ & $\begin{array}{l}5.8 \\
5.8 \\
\mathrm{NS}\end{array}$ \\
\hline & & & & & & & & \\
\hline $\begin{array}{l}\text { Iron supplied...... } \\
\text { No iron supplied.... } \\
\text { Significance . . . . . }\end{array}$ & $\begin{array}{l}\cdots \\
\cdots \\
\cdots\end{array}$ & $\begin{array}{l}\cdots \\
\cdots \\
\cdots\end{array}$ & $\begin{array}{l}\cdots \\
\cdots \\
\cdots\end{array}$ & $\begin{array}{l}0.19 \\
0.19 \\
\text { NS }\end{array}$ & $\begin{array}{r}14.4 \\
10.2 \\
* * *\end{array}$ & $\begin{array}{l}2.4 \\
2.2 \\
\text { NS }\end{array}$ & $\begin{array}{l}5.1 \\
4.9 \\
\text { NS }\end{array}$ & $\begin{array}{l}4.2 \\
3.8 \\
\text { NS }\end{array}$ \\
\hline \multirow{3}{*}{$\begin{array}{l}\text { Iron supplied...... } \\
\text { No iron supplied.... } \\
\text { Significance. . . . . }\end{array}$} & \multicolumn{8}{|c|}{ Rind } \\
\hline & $\begin{array}{l}\cdots \\
\cdots \\
\cdots\end{array}$ & $\begin{array}{l}\cdots \\
\cdots \\
\cdots\end{array}$ & $\begin{array}{l}\cdots \\
\cdots \\
\cdots\end{array}$ & $\begin{array}{l}0.12 \\
0.12 \\
\text { NS }\end{array}$ & $\begin{array}{r}16.8 \\
12.3 \\
* * *\end{array}$ & $\begin{array}{l}4.7 \\
4.0 \\
\text { NS }\end{array}$ & $\begin{array}{l}6.5 \\
5.6 \\
*\end{array}$ & $\begin{array}{l}3.5 \\
3.7 \\
\mathrm{NS}\end{array}$ \\
\hline & \multicolumn{8}{|c|}{ Juice } \\
\hline \multirow[t]{2}{*}{$\begin{array}{l}\text { 1960: } \\
\text { Iron supplied ....... } \\
\text { No iron supplied.... } \\
\text { Significance. . . . . . }\end{array}$} & $\begin{array}{r}.64 \\
.67 \\
\mathrm{NS}\end{array}$ & $\begin{array}{l}0.13 \\
0.14 \\
\mathrm{NS}\end{array}$ & $\begin{array}{l}1.4 \\
1.6 \\
\text { NS }\end{array}$ & $\begin{array}{l}0.16 \\
0.17 \\
\mathrm{NS}\end{array}$ & $\begin{array}{l}9.9 \\
5.6 \\
* * *\end{array}$ & $\begin{array}{l}1.5 \\
1.4 \\
\mathrm{NS}\end{array}$ & $\begin{array}{l}3.8 \\
2.4 \\
\mathrm{NS}\end{array}$ & $\begin{array}{l}3.6 \\
3.0 \\
\mathrm{NS}\end{array}$ \\
\hline & \multicolumn{8}{|c|}{ Pulp } \\
\hline $\begin{array}{l}\text { Iron supplied ....... } \\
\text { No iron supplied.... } \\
\text { Significance. . . . . . }\end{array}$ & $\begin{array}{l}1.08 \\
1.15 \\
\text { NS }\end{array}$ & $\begin{array}{l}0.12 \\
0.12 \\
\text { NS }\end{array}$ & $\begin{array}{l}1.1 \\
1.2 \\
\text { NS }\end{array}$ & $\begin{array}{l}0.15 \\
0.15 \\
\text { NS }\end{array}$ & $\begin{array}{r}11.8 \\
4.5 \\
* * *\end{array}$ & $\begin{array}{c}1.9 \\
1.6 \\
*\end{array}$ & $\begin{array}{c}4.8 \\
3.9 \\
* *\end{array}$ & $\begin{array}{c}2.9 \\
2.1 \\
*\end{array}$ \\
\hline & \multicolumn{8}{|c|}{ Rind } \\
\hline $\begin{array}{l}\text { Iron supplied ...... } \\
\text { No iron supplied.... } \\
\text { Significance. . . . . . }\end{array}$ & $\begin{array}{l}2.44 \\
2.67 \\
*\end{array}$ & $\begin{array}{l}0.13 \\
0.12 \\
\mathrm{NS}\end{array}$ & $\begin{array}{l}0.7 \\
0.7 \\
\text { NS }\end{array}$ & $\begin{array}{l}0.11 \\
0.11 \\
\text { NS }\end{array}$ & $\begin{array}{r}13.4 \\
6.5 \\
* * *\end{array}$ & $\begin{array}{l}4.5 \\
3.0 \\
* * *\end{array}$ & $\begin{array}{c}7.3 \\
6.2 \\
* *\end{array}$ & $\begin{array}{c}3.2 \\
2.4 \\
* *\end{array}$ \\
\hline
\end{tabular}

* Significant at the .05 level.

*** Significant at the .01 level.

*** Significant at the .001 level.

$\mathrm{NS}=$ Not found to be significant.

is possible for leaves in successive cycles to exhibit various levels of iron nutrition, depending on the rate of iron supply at the time the particular leaf developed. By contrast, much of the nitrogen, phosphorus, and potassium in plant tissues appear to be mobile, and deficiency of any one of these elements tends to be reflected promptly in com- position of leaves of all ages and in growth and productivity of the plant.

The declining rate of trunk growth under conditions of iron deficit (table 9 ) indicated that growth rate of the entire tree was probably reduced. Part of the reduction in fruit yield was, therefore, attributable to tree size. However, actual trunk circumference meas- 


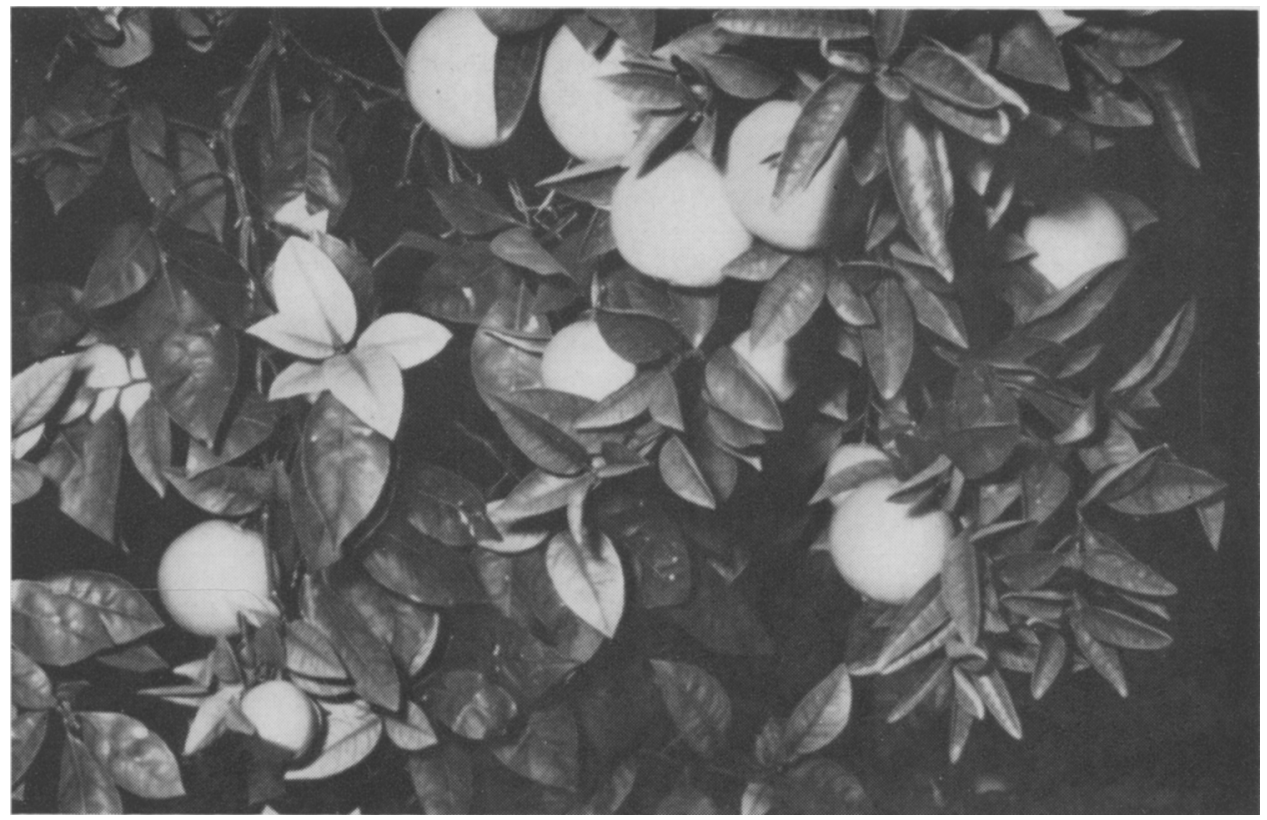

Fig. 4. Part of a tree in which chlorotic young leaves acquired iron and became dark green rather rapidly. August, 1961.

urements at the end of the experiment did not show any difference between the low-iron trees and high-iron trees, so the effect of this factor on fruit production was presumably of minor importance throughout this experiment.

The absence of a clear relation between fruit production and rate of trunk growth may reflect a low degree of precision in measuring radial increments in trunks, or it may indicate that radial increment is not a sensitive index of total growth. On the other hand, there may be a physiological reason involved, based on the mechanism by which iron deficit limits fruit production. In spite of the fact that fewer fruits were matured by the low-iron trees, individual fruits tended to be somewhat larger. This suggests that the limitation of fruit numbers was sometimes excessive and that the tree was capable of contributing more energy to fruit growth in proportion to numbers. In such cases, the contribution to trunk growth may also have been greater than it would have been had more fruits been grown to maturity. The fact that lowiron trees produced significantly larger fruit and greater trunk growth in 1959 supports this suggestion.

The data on fruit production and trunk growth (tables 4 and 9) further indicate that iron concentrations of 30 ppm or below in standard leaves reflect iron deficiency. It was not possible to demonstrate that the deficiency range included leaf iron values higher than 30 ppm. Within the limits of precision of this experiment, therefore, the critical concentration of iron in standard leaves-with respect to fruit production-was $30 \mathrm{ppm}$ or slightly above. This agrees substantially with the figure of $35 \mathrm{ppm}$ adopted by Reuther and Smith (1954).

Previous data (Wallihan, 1955) indicated that orange leaves with $35 \mathrm{ppm}$ of iron contain less than half as much chlorophyll as do "normal" dark green leaves. Some recent tests indicate that the figure is closer to three-fourths. Multiple deficiencies affecting chlorophyll concentration may account for 


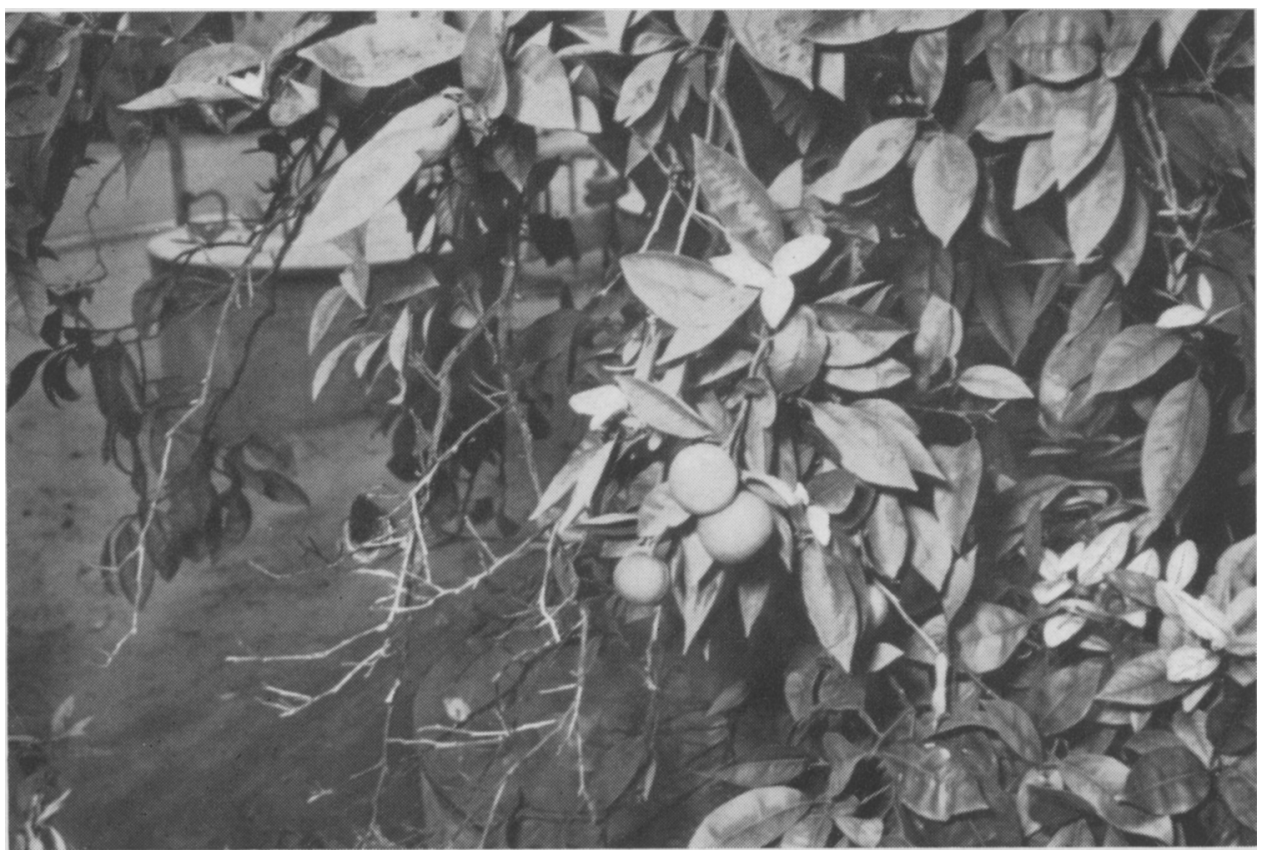

Fig. 5. Part of a tree in which chlorotic young leaves became somewhat greener with age but did not achieve a normal concentration of chlorophyll. Dead twigs were typical of this stage of iron deficiency, which was associated with concentrations of 15 to $20 \mathrm{ppm}$ of iron in standard leaves. August, 1961.

TABLE 9

AVERAGE INCREMENTS IN TRUNK CIRCUMFERENCES IN RELATION TO LEAF IRON CONCENTRATIONS, IN SUCCESSIVE YEARS

\begin{tabular}{|c|c|c|c|c|}
\hline \multirow{2}{*}{$\begin{array}{l}\text { Trees grouped } \\
\text { according to } \\
\text { leaf iron } \\
\text { concentrations }\end{array}$} & \multicolumn{4}{|c|}{$\begin{array}{l}\text { Average increment of trunk } \\
\text { circumference }\end{array}$} \\
\hline & 1958 & 1959 & 1960 & 1961 \\
\hline $30 \mathrm{ppm}$ or less & $\mathrm{cm}$ & $\mathrm{cm}$ & $\mathrm{cm}$ & $\mathrm{cm}$ \\
\hline $\begin{array}{l}(8) \dagger \ldots \ldots \\
\text { More than } 30\end{array}$ & 1.70 & 2.42 & 1.14 & 0.69 \\
\hline ppm (15). & 2.15 & 1.81 & 1.61 & 1.21 \\
\hline Significance. & NS & $*$ & NS & $* *$ \\
\hline
\end{tabular}

** Significant at the .05 level.

** Significant at the .01 level.

$\dagger$ In three out of four years.

$\mathrm{NS}=$ Not found to be significant

this discrepancy. In any case, orange leaves with $30 \mathrm{ppm}$ iron have less than the maximum chlorophyll concentrations. Therefore, the critical concentration of iron for fruit production appears to be lower than that for chlorophyll development.
High leaf iron concentrations were sometimes accompanied by low fruit production, which raises the question of an adverse effect of high iron levels on fruit production. This seems improbable in view of the normal occurrence of leaf iron concentrations up to $135 \mathrm{ppm}$ in high-producing citrus trees. A more probable explanation is that, in years and trees of high growth rate, iron uptake failed to keep pace and concentrations in tissues were diluted. The reciprocal relation shown in figures 1 and 2 apparently was brought about in this way. Thus, it appears that the weekly addition of $0.2 \mathrm{mg}$ of iron (as $\mathrm{FeSO}_{4}$ ) to the nutrient solutions was not adequate, under all conditions, to maintain high iron concentrations in the trees. This point is supported by the progressive decrease in leaf iron concentrations in the high-iron trees in successive years.

Although fruit from low-iron trees had significantly higher percentage of 


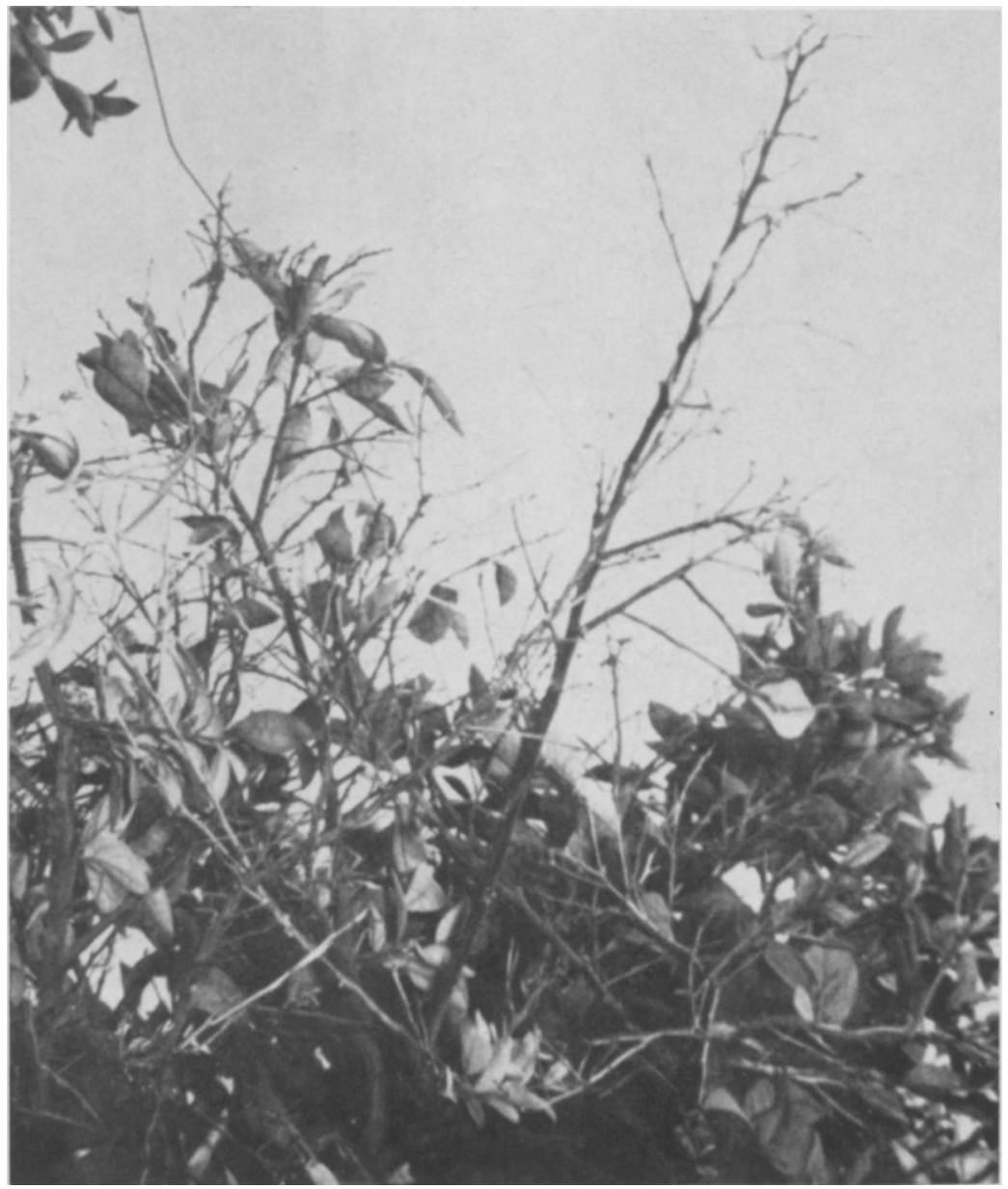

Fig. 6. Extensive dieback that resulted from severe iron deficiency. August, 1961.

rind by weight, and the juice contained a lower concentration of sugar, the differences were not large. Likewise, flavor and texture were not obviously affected. The orange coloration of such fruit was visibly less intense than in fruit from treated trees. This was also observed in some (though not all) orchards in the field. It is quite possible that daily and seasonal trends in iron supply to these trees grown in solution culture were quite different from those in some field orchards. This may account for different effects on fruit quality from iron deficit. Different varieties may also respond differently to iron deficit.

As pointed out in a previous section, the present experiment was limited in duration by tree crowding, both in the canopies and in the tanks. The pattern of fruit production in orange trees is such that studies of this type would probably yield most useful data in the age range from 10 to 15 years. Tanks should be spaced the same as field trees for this purpose-about $20 \times 20$ feet on centers, and should be larger in diameter-perhaps 8 to 10 feet. Since plant roots tend to float in water, a tank depth of 2 or 3 feet might be adequate. Three or four aerators in each tank might be needed, although shallow tanks would favor aeration. 


\section{LITERATURE CITED}

BAtchelor, L. D., E. R. PARker, and Robert McBride

1928. Studies preliminary to the establishment of a series of fertilizer trials in a bearing citrus grove. California Agr. Exp. Sta. Bul. 451: 49 pp.

Bingham, F. T., J. P. Martin, and J. A. Chastain

1958. Effects of phosphorus fertilization of California soils on minor element nutrition of citrus. Soil Sci. 86:24-31.

Cameron, S. H., and D. Appleman

1934. The distribution of total nitrogen in the orange tree. Amer. Soc. Hort. Sci. Proc. $30: 341-48$.

Chapman, H. D., and S. M. Brown

1941. The effects of sulfur deficiency on citrus. Hilgardia 14:185-201.

Chapman, H. D., S. M. Brown, and D. S. Rayner

1947. Effects of potash deficiency and excess on orange trees. Hilgardia 17:619-50.

Chapman, H. D., and G. F. Liebig, JR.

1940. Nitrate concentration balance in relation to citrus nutrition. Hilgardia 13:141-73.

Chapman, H. D., and P. F. PratT

1961. Methods of analysis for soils, plants, and waters. University of California Division of Agricultural Sciences. 309 pp. Illus. Ref.

Chapman, H. D., and D. S. Rayner

1951. Effect of various maintained levels of phosphate on the growth, yield, composition, and quality of Washington Navel oranges. Hilgardia $20: 325-58$.

Chapman, H. D., E. F. Wallihan, D. S. Rayner, and Harrietann Joseph

1958. Citrus trees in water cultures. California Agr. $12(3): 3-4$.

Cullinan, F. P., and L. P. BAtJer

1943. Nitrogen, phosphorus, and potassium interrelations in young peach and apple trees. Soil Sci. 55:49-60.

Fiske, C. H., and Y. SubBarow

1925. The colorimetric determination of phosphorus. Jour. Biol. Chem. 66:375-400.

HaAs, A. R. C.

1936. Phosphorus content of citrus and factors affecting it. Soil Sci. 41:239-58.

ILJIN, W. S.

1952. Metabolism of plants affected with lime-induced chlorosis (calciose). III. Mineral elements. Plant and Soil IV:11-28.

JACOBSON, L.

1945. Iron in the leaves and chloroplasts of some plants in relation to their chlorophyll content. Plant Physiol. $20: 233-45$.

Johnson, C. M., and A. UlRICH

1959. Analytical methods-for use in plant analysis. California Agr. Exp. Sta. Bul. 766.

Kelley, W. P., and A. B. Cummins

1920. Composition of normal and mottled citrus leaves. Jour. Agr. Res. 20:161-91.

McCalla, A. G., and E. K. Woodford

1938. Effects of a limiting element on the absorption of individual elements and on the anioncation balance in wheat. Plant Physiol. 13:695-712.

McGeorge, W. T.

1949. A study of lime-induced chlorosis in Arizona orchards. Arizona Agr. Exp. Sta. Tech. Bul. 117:341-88.

REED, H. S.

1946. Effects of zine deficiency on phosphate metabolism of the tomato plant. Amer. Jour. Bot. 33:778-84.

REUTHER, W., and P. F. SMITH

1954. Fruit nutrition. Chapter 7. Somerset Press, Somerville, N.J., 907 pp.

SANDELL, E. B.

1950. Colorimetric determination of traces of metals. Second Edition. Interscience Publishers, Inc., N.Y.

Smith, P. F., and W. Reuther

1950. Seasonal changes in valencia orange trees. I. Changes in leaf dry weight, ash, and macronutrient elements. Amer. Soc. Hort. Sci. Proc. 55:61-72 
Smith, P. F., W. Reuther, and A. W. Specht

1950. Mineral composition of chlorotic orange leaves and some observations on the relation of sample preparation technique to the interpretation of results. Plant Physiol. 25(3):496506.

1952. Seasonal changes in valencia orange trees. II. Changes in micro-elements, sodium, and carbohydrates in leaves. Amer. Soc. Hort. Sci. Proc. 59:31-35.

Stewart, I., and C. D. LeONARD

1954. What chelates are. Nat. Fert. Rev. 29(4):9-11.

WALLIHAN, E. F.

1955. Relation of chlorosis to concentration of iron in citrus leaves. Amer. Jour. Bot. 42:10104.

Wallihan, E. F., and T. W. EMbleton

1961. Iron chlorosis. California Citrog. $46: 67,87,89$.

In our publications it is sometimes convenient to use trade names of products or equipment rather than scientific identifications. In so doing it is unavoidable in some cases that similar products which are on the market under other trade names may not be cited. No endorsement of named products is intended nor is criticism implied of similar products which are not mentioned. 
The journal HILGARDIA is published at irregular intervals, in volumes of about 650 to 700 pages. The number of issues per volume varies.

Single copies of any issue may be obtained free, as long as the supply lasts; please request by volume and issue number from:

$$
\begin{aligned}
& \text { Agricultural Publications } \\
& \text { University Hall } \\
& \text { University of California } \\
& \text { Berkeley, California } \mathbf{9 4 7 2 0}
\end{aligned}
$$

The limit to nonresidents of California is 10 separate titles. The limit to California residents is 20 separate titles.

The journal will be sent regularly to libraries, schools, or institutions in one of the following ways:

1. In exchange for similar published material on research.

2. As a gift to qualified repository libraries only.

3. On a subscription basis- $\$ 7.50$ a year paid in advance. All subscriptions will be started with the first number issued during a calendar year. Subscribers starting during any given year will be sent back numbers to the first of that year and will be billed for the ensuing year the following January. Make checks or money orders payable to The Regents of The University of California; send payment with order to Agricultural Publications at above address. 